\title{
The Effect of Leadership, Apparatus Professionality, and Work Facilities on the Quality of Ship Services and Goods in the Main Port Authority Office of Tanjung Priok
}

\author{
Hermanta $^{1}$, Josy Adiwisastra ${ }^{1}$, Musa Hubeis ${ }^{1}$, Dewi Sulistyani ${ }^{1}$ \\ ${ }^{1}$ Doctoral Study Program of Governmental Science, Satyagama University, Indonesia
}

\begin{abstract}
This study aims to determine the effect of leadership, the professionalism of the apparatus and work facilities on the quality of service both partially and collectively. The sampling technique in this study was proportionate stratified random sampling with a sample of 313 respondents. This research method is a quantitative method with regression analysis. Data collection techniques using documentation techniques, literature study, questionnaires, and observations. The research data collection tool was a questionnaire based on a Likert scale. The data analysis techniques in this study were validity test, reliability test, normality test, linearity test, multicollinearity test, heteroscedasticity test, $\mathrm{F}$ test and t-test, simple and multiple linear regression. The results of the study prove that there is a positive influence of leadership on service quality by $82 \%$. Second, there is a positive influence on the professionalism of the officers on the quality of service by $79.3 \%$. Third, there is a positive effect of work facilities on service quality by $80.2 \%$. Fourth, there is a positive influence of leadership, apparatus professionality, and work facilities together on service quality of 83.9\%. The quality of ship and goods services at the Tanjung Priok Main Port Authority Office can be achieved through effective leadership, a high level of professionalism of the officials, and adequate work facilities. These three variables must be considered so that the quality of ship and goods services can satisfy service users.
\end{abstract}

Keywords: Leadership, Professionalism, Facilities, Service Quality

Received: October 26, 2020

Received in Revised: November 8, 2020

Accepted: November 10, 2020

\section{Introduction}

Excellent public service is one of the manifestations of good governance. Good governance is a new paradigm in governance management. Good governance or good governance is an implementation of responsible development management, in line with democratic, effective, and efficient principles. In addition, the aspired government must be able to involve the community and entrepreneurs in providing social control, so as to create openness, equality, and balance for all citizens who need public services (Doherty \& Horne, 2002).

One form of public service that is carried out by the government is the implementation of public services at ports, which is the mandate of Law Number 17 of 2008 concerning Shipping, which is implemented in the form of port public service arrangements. For this reason, the Ministry of Transportation of the Republic of Indonesia has set seven priorities or Quick Win in 2018. Quick Win is an instruction from the Minister of Transportation of the Republic of Indonesia to the Directorate General of Land Transportation, Directorate General of Sea Transportation, Directorate General of Civil Aviation, Directorate General of Railways, Jabodetabek Transportation Management Agency (BPTJ), Transportation Human Resources (HR) Development Agency, and Transportation Research and Development Agency.

One of the instructions is for the Directorate General of Sea Transportation to immediately

Copyright (C) 2020, International Journal Papier Public Review, Under the license CC BY-SA 4.0 DOI: https://doi.org/10.47667/ijppr.v1i2.37 
implement modern services (Smart Port) with all online-based services at Indonesian ports. As a follow-up in integrating standardized port information systems in serving ships and goods physically from all agencies and stakeholders, the Ministry of Transportation implemented Inaportnet, which is an internet-based electronic single service information system to integrate standard port information systems. in serving ships and goods from all related agencies at the port including the Port Business Entity service system.

Previously in order to improve the effectiveness and efficiency of the implementation of duties and functions in the field of shipping safety and security, as well as regulating, controlling, and supervising port activities, the Ministry of Transportation of the Republic of Indonesia officially changed the nomenclature of the Technical Implementation Unit (UPT) within the Directorate General of Sea Transportation. (Ditjen Hubla).

The Tanjung Priok Main Port Authority is one of the first priorities for implementing the Quick Win program at the Ministry of Transportation of the Republic of Indonesia which must implement Inaportnet, in addition to the main ports of Tanjung Priok the other ports are Tanjung Perak Surabaya, Belawan Medan, and Makassar South Sulawesi. The Inaportnet system has been implemented in 4 (four) main ports and 13 (thirteen) Class I and II ports.

The next problem is the influence of professionalism of the authorities, especially in the implementation of the quality ship and goods services at the Tanjung Priok Main Port Authority. As it is known, the success and smooth running of services, apart from being supported by transformational leadership, are also influenced by high apparatus professionalism.

However, in reality, the capacity of the apparatus resources in providing services to port service users, as well as the attitude of behavior in anticipating problems that occur, are often not in accordance with the expectations of service users. It can be seen that the level of professionalism of the apparatus in providing public services is still low.

The problem with the low level of professionalism of the apparatus is indicated by the fact that there are still some officers who have not been able to provide complete service to ports. This can be seen where some officers are still indicated by a lack of knowledge, skills, skills, attitudes, and behaviors required in carrying out their main tasks, functions of the authority, and responsibility that is mandated to them, thus affecting the service of ships and quality goods. For example, when a service user needs a solution to problems in ship service and the goods that occur, the authorities are unable to provide satisfactory answers/solutions related to these problems. Lack of responsiveness to the needs of service users, low ability to organize problems faced when providing services, and lack of ability to analyze problems that occur, so this makes service users disappointed or the acceptance of unsatisfactory services. The low level of professionalism of some officers can be caused by recruitment and placement problems that are not in accordance with the educational background and professionalism of other officials including the level of knowledge, skill level, and attitude/behavior.

In addition to the influence of leadership and professionalism of the authorities to realize quality ship and goods services, it must always be balanced with support in the form of adequate work facilities (Gronn, 2003; Bate et al., 2007). The problem of work facilities related to service of ships and quality goods, in general, is marked by the unfulfilled needs for work support facilities so that it affects a quality ship and goods services at the Tanjung Priok Main Port Authority. This is partly due to the limited budget originating from the State Budget through the Ministry of Transportation of the Republic of Indonesia, the inability to plan priority goods needs programs and in accordance with developments in science and 
technology. This study aims to determine the effect of leadership, the professionalism of the apparatus and work facilities on the quality of service both partially and collectively.

\section{Methods}

The research method used in this study uses a quantitative research approach. The type of this research is explanatory research. The data analysis model of this study used simple and multiple linear regression. The location of this research was conducted in the Tanjung Priok Port Authority Office Area, North Jakarta, DKI Jakarta Province.

The sampling technique in this study was proportionate stratified random sampling with a sample of 313 respondents from 1446 people in the total population.

Data collection techniques using documentation techniques, literature study, questionnaires, and observations. This research data collection tool is a questionnaire based on a Likert scale. The data analysis techniques in this study were validity test, reliability test, normality test, linearity test, multicollinearity test, heteroscedasticity test, F-test and t-test, simple and multiple linear regression.

\section{Results and Discussion}

\section{Leadership}

Based on the results of the analysis, the statistical description of the leadership variable (X1) is obtained as follows: (1) The minimum value is 3.73. (2) The maximum value is 4.87. (3) The value range is 1.14. (4) The average/mean value is 4.4639. (5) The standard deviation/standard deviation is 0.36599 . (6) The variance of 0.134 .

Table 1. Frequency Distribution of Leadership Variables X1

\begin{tabular}{|l|l|r|r|r|r|}
\hline \multicolumn{2}{|c}{ Frequency } & Percent & $\begin{array}{c}\text { Valid } \\
\text { Percent }\end{array}$ & $\begin{array}{c}\text { Cumulative } \\
\text { Percent }\end{array}$ \\
\hline \multirow{4}{*}{ Valid } & 3.73 & 19 & 6.1 & 6.1 & 6.1 \\
\cline { 2 - 6 } & 3.8 & 18 & 5.8 & 5.8 & 11.8 \\
\cline { 2 - 6 } & 4 & 38 & 12.1 & 12.1 & 24.0 \\
\cline { 2 - 6 } & 4.33 & 19 & 6.1 & 6.1 & 30.0 \\
\cline { 2 - 6 } & 4.4 & 34 & 10.9 & 10.9 & 40.9 \\
\hline & 4.6 & 75 & 24.0 & 24.0 & 64.9 \\
\cline { 2 - 6 } & 4.73 & 38 & 12.1 & 12.1 & 77.0 \\
\cline { 2 - 6 } & 4.8 & 19 & 6.1 & 6.1 & 83.1 \\
\cline { 2 - 6 } & 4.87 & 53 & 16.9 & 16.9 & 100.0 \\
\cline { 2 - 6 } & Total & 313 & 100.0 & 100.0 & \\
\hline
\end{tabular}

Source: Output SPPS 21

Based on the results of statistical frequency analysis, it can be seen that $88.2 \%$ of respondents agreed that leadership plays an important role in the service of quality ships and goods. Leadership in question is a way that is a fixed pattern of influencing people to move in the direction the leader wants.

In order for quality ship and goods services in the perspective of authority at the Tanjung Priok Main Port Authority Office to be realized and to satisfy service users, it is necessary to have effective leadership that has techniques for maturing and preparing followers, human 
relations techniques, modeling techniques, persuasion techniques and giving orders and usage techniques. a suitable communication system in providing quality and satisfying services.

\section{Apparatus Professionalism}

Based on the results of the analysis, the statistical description of the Apparatus Professionalism (X2) variable is as follows: (1) The minimum value is 3.60 ; (2) The maximum value is 4.73 . (3) The value range is 1.13 . (4) The average/mean value is 4.3684 . (5) The standard deviation/standard deviation is 0.41974. (6) The variance is 0.176.

Table 2. Frequency Distribution of Apparatus Professionalism Variable X2

\begin{tabular}{|l|l|r|r|r|r|}
\hline \multicolumn{2}{|c|}{} & Frequency & Percent & $\begin{array}{c}\text { Valid } \\
\text { Percent }\end{array}$ & $\begin{array}{c}\text { Cumulative } \\
\text { Percent }\end{array}$ \\
\hline \multirow{4}{*}{ Valid } & 3.6 & 38 & 12.1 & 12.1 & 12.1 \\
\cline { 2 - 6 } & 3.67 & 19 & 6.1 & 6.1 & 18.2 \\
\cline { 2 - 6 } & 3.73 & 18 & 5.8 & 5.8 & 24.0 \\
\cline { 2 - 6 } & 4.4 & 53 & 16.9 & 16.9 & 40.9 \\
\cline { 2 - 6 } & 4.53 & 37 & 11.8 & 11.8 & 52.7 \\
\cline { 2 - 6 } & 4.6 & 38 & 12.1 & 12.1 & 64.9 \\
\cline { 2 - 6 } & 4.67 & 38 & 12.1 & 12.1 & 77.0 \\
\cline { 2 - 6 } & 4.73 & 72 & 23.0 & 23.0 & 100.0 \\
\cline { 2 - 6 } & Total & 313 & 100.0 & 100.0 & \\
\hline
\end{tabular}

Source: Output SPPS 21

Based on the results of statistical frequency analysis, it can be seen that the professionalism of the apparatus is agreed upon by $76 \%$ of the respondents as having an important role in the service of quality ships and goods. Apparatus professionalism is the ability and skills of a person to do work according to their respective fields and levels.

In order for quality ship and goods services in the perspective of authority at the Tanjung Priok Main Port Authority Office to be realized and satisfying, it is necessary to have high professionalism of officials who have a high level of knowledge, skill level, and attitude/behavior in providing quality and satisfying services.

\section{Work Facilities}

Based on the results of the analysis, the statistical description of the work facilities (X3) variable is as follows: (1) The minimum value is 3.67. (2) The maximum value is 4.73 (3) The value range is 1.06 (4) The average value is 4.4084 (5) The standard deviation is 0.36111 (6) The variance is 0.130 .

Table 3. Variable Frequency Distribution of Work Facilities X3

\begin{tabular}{|c|l|r|r|r|r|}
\hline \multicolumn{2}{|c|}{} & Frequency & Percent & \multicolumn{1}{c|}{$\begin{array}{c}\text { Valid } \\
\text { Percent }\end{array}$} & $\begin{array}{l}\text { Cumulative } \\
\text { Percent }\end{array}$ \\
\hline \multirow{4}{*}{ Valid } & 3.67 & 18 & 5.8 & 5.8 & 5.8 \\
\cline { 2 - 6 } & 3.8 & 19 & 6.1 & 6.1 & 11.8 \\
\cline { 2 - 6 } & 3.87 & 38 & 12.1 & 12.1 & 24.0 \\
\cline { 2 - 6 } & 4.27 & 19 & 6.1 & 6.1 & 30.0 \\
\cline { 2 - 6 } & 4.33 & 15 & 4.8 & 4.8 & 34.8 \\
\hline
\end{tabular}




\begin{tabular}{|l|l|r|r|r|r|}
\hline 4.53 & 19 & 6.1 & 6.1 & 40.9 \\
\cline { 2 - 6 } & 4.6 & 38 & 12.1 & 12.1 & 53.0 \\
\cline { 2 - 6 } & 4.67 & 129 & 41.2 & 41.2 & 94.2 \\
\hline 4.73 & 18 & 5.8 & 5.8 & 100.0 \\
\hline
\end{tabular}

Source: Output SPPS 21

Based on the results of statistical frequency analysis, it can be seen that $76 \%$ of respondents agreed that work facilities play an important role in the service of quality ships and goods. The work facility in question is a means of supporting physical organizational activities, and is used in the normal activities of the organization, has a relatively permanent period of use and provides benefits for the future.

In order for quality ship and goods services in the perspective of authority at the Tanjung Priok Main Port Authority Office to be realized and satisfactory, it is necessary to have adequate work facilities in the form of infrastructure, office, and building equipment, transportation means in order to provide quality and satisfying services.

\section{Public Service (Ship and Goods)}

Based on the analysis results, the statistical description of the Public Service variable (X1) is as follows: (1) The minimum value is 4.13 (2) The maximum value is 5.00 (3) The value range is 0.87 (4) The average value is 4.63906 (5) Standard deviation / standard deviation of 0.29970 (6) Variance of 0.090.

Based on the results of statistical frequency analysis, it can be seen that $100 \%$ of respondents stated the importance of ship and goods services by the Tanjung Priok Main Port Authority which satisfies the user community, as it should be. This is indicated by the large average value of respondents' perceptions and this condition cannot be separated from the role represented by the leadership, professionalism of officials, and work facilities.

Table 4. Frequency Distribution of Public Service Variables Y

\begin{tabular}{|l|l|r|r|r|r|}
\hline \multicolumn{2}{|c|}{} & Frequency & Percent & $\begin{array}{c}\text { Valid } \\
\text { Percent }\end{array}$ & $\begin{array}{l}\text { Cumulative } \\
\text { Percent }\end{array}$ \\
\hline \multirow{7}{*}{ Valid } & 4.13 & 18 & 5.8 & 5.8 & 5.8 \\
\cline { 2 - 6 } & 4.2 & 57 & 18.2 & 18.2 & 24.0 \\
\cline { 2 - 6 } & 4.47 & 53 & 16.9 & 16.9 & 40.9 \\
\cline { 2 - 6 } & 4.8 & 56 & 17.9 & 17.9 & 58.8 \\
\cline { 2 - 6 } & 4.87 & 76 & 24.3 & 24.3 & 83.1 \\
\cline { 2 - 6 } & 4.93 & 34 & 10.9 & 10.9 & 93.9 \\
\cline { 2 - 6 } & 5 & 19 & 6.1 & 6.1 & 100.0 \\
\cline { 2 - 6 } & Total & 313 & 100.0 & 100.0 & \\
\hline
\end{tabular}

Source: Output SPPS 21

In order for quality ship and goods services in the perspective of authority at the Tanjung Priok Main Port Authority Office to be realized and to satisfy service users, the principles of transparency, accountability, conditionality, participation, equality of rights, the balance of rights and obligations are needed, so that these services can satisfy the service user community. in general. 


\section{Testing Requirements Analysis}

Testing the requirements of the analysis results in this study consisted of data instrument tests, basic assumption tests, and classical assumption tests, each of which was tested. The validity test is used to measure whether a questionnaire is valid or not. A questionnaire is said to be valid if the questions on the questionnaire are able to measure the variable to be measured. The validity test in this study uses Pearson's Product Moment Coefficient $r$ with decision-making criteria as stated by Ghozali (2016: 53), that is, if r-count> r-table, then the question is declared valid. Conversely, if r-count $\leq$ r-table then the question is declared invalid.

Based on the results of the validity test of the research questionnaire that was tested on 313 (n $=313$ ) respondents with 15 items of instruments/statements on the questionnaire, the following results were obtained:

Table 5. The Results of the Leadership Variable Validity Test (X1)

\begin{tabular}{|c|c|c|c|}
\hline $\begin{array}{c}\text { No. } \\
\text { Questionnaire }\end{array}$ & r-count & r-table & Description \\
\hline 1 & 0.699 & & \\
\hline 2 & 0.670 & & \\
\hline 3 & 0.519 & & \\
\hline 4 & 0.670 & & \\
\hline 5 & 0.836 & & \\
\hline 6 & 0.729 & & \multirow{2}{*}{ Valid } \\
\hline 7 & 0.715 & \\
\hline 8 & 0.417 & & \\
\hline 9 & 0.798 & & \\
\hline 10 & 0.637 & & \\
\hline 11 & 0.630 & & \\
\hline 12 & 0.682 & & \\
\hline 13 & 0.772 & & \\
\hline 14 & 0.749 & & \\
\hline 15 & 0.632 & & \\
\hline
\end{tabular}

Source: Output SPSS 21

Based on the table of the results of the validity test above, it can be seen that all the values of $\mathrm{r}$-count to test the validity of the Leadership variable instrument (X1) are in fact the average value is greater than the r-table (0.113). This means that all statement items in the research questionnaire are declared valid.

Table 6. Validity Test Results of Apparatus Professionalism Variable (X2)

\begin{tabular}{|c|c|c|c|}
\hline $\begin{array}{c}\text { No. } \\
\text { Questionnaire }\end{array}$ & r-count & r-table & Description \\
\hline 1 & 0.704 & & \\
\hline 2 & 0.658 & & \\
\hline 3 & 0.640 & \multirow{2}{*}{0,113} & \multirow{2}{*}{ Valid } \\
\hline 4 & 0.807 & & \\
\hline 5 & 0.693 & & \\
\hline 6 & 0.867 & & \\
\hline 7 & 0.755 & & \\
\hline
\end{tabular}




\begin{tabular}{|c|c|}
\hline 8 & 0.601 \\
\hline 9 & 0.704 \\
\hline 10 & 0.599 \\
\hline 11 & 0.347 \\
\hline 12 & 0.869 \\
\hline 13 & 0.674 \\
\hline 14 & 0.962 \\
\hline 15 & 0.667 \\
\hline
\end{tabular}

Source: Output SPSS 21

Based on the table of the results of the validity test above, it can be seen that all the values of r-count for the validity test of the Apparatus Professionalism variable (X2) are in fact the average value is greater than the r-table (0.113). This means that all statement items in the research questionnaire are declared valid.

Table 7. Validity Test Results of Work Facilities Variable (X3)

\begin{tabular}{|c|c|c|c|}
\hline $\begin{array}{c}\text { No. } \\
\text { Questionnaire }\end{array}$ & r-count & r-table & Description \\
\hline 1 & 0.699 & & \\
\hline 2 & 0.941 & & \\
\hline 3 & 0.781 & & \\
\hline 4 & 0.586 & & \\
\hline 5 & 0.704 & & \multirow{3}{*}{ Valid } \\
\hline 6 & 0.883 & \multirow{3}{*}{0,113} & \\
\hline 7 & 0.503 & \\
\hline 8 & 0.743 & & \\
\hline 9 & 0.837 & & \\
\hline 10 & 0.838 & & \\
\hline 11 & 0.725 & & \\
\hline 12 & 0.730 & & \\
\hline 13 & 0.559 & & \\
\hline 14 & 0.622 & & \\
\hline 15 & 0.560 & & \\
\hline
\end{tabular}

Source: Output SPSS 21

Based on the table of the results of the validity test above, it can be seen that the values of the correlation coefficient (r-count) for the validity test of the Work Facilities variable instrument (X3) turned out to be the average value greater than the r-table (0.113). This means that all items of the research questionnaire statement are declared valid.

Table 8. Validity Test Results of Goods and Ships Service Variables (Y)

\begin{tabular}{|c|c|c|c|}
\hline $\begin{array}{c}\text { No. } \\
\text { Questionnaire }\end{array}$ & r-count & r-table & Description \\
\hline 1 & 0.849 & \multirow{5}{*}{} & \\
\hline 2 & 0.567 & & \\
\hline 3 & 0.511 & & \\
\hline 4 & 0.578 & & \\
\hline 5 & 0.831 & & \\
\hline 6 & 0.547 & & \\
\hline
\end{tabular}




\begin{tabular}{|c|l|l|l|}
\hline 7 & 0.777 & \multirow{2}{*}{0,113} & \multirow{2}{*}{ Valid } \\
\hline 8 & 0.805 & & \\
\hline 9 & 0.781 & & \\
\hline 10 & 0.520 & & \\
\hline 11 & 0.724 & & \\
\hline 12 & 0.454 & & \\
\hline 13 & 0.331 & & \\
\hline 14 & 0.740 & & \\
\hline 15 & 0.685 & & \\
\hline
\end{tabular}

Source: Output SPSS 21

Based on the table of the results of the validity test above, it can be seen that the values of the correlation coefficient (r-count) for the validity test of the Goods and Ships Service variable instrument $(\mathrm{Y})$ are in fact the average value is greater than the r-table (0.113). This means that all statement items in the research questionnaire are declared valid.

\section{Reliability Test}

The reliability test is used to measure the consistency of the measurement results of the questionnaire in repeated use. Consistency here means that the numerical numbers generated by an indicator do not vary due to the characteristics of the measurement process or the measurement instrument itself. According to Neuman \& Kreuger (2003), reliability is the degree to which the measurements are made to obtain consistent results. Reliability is the consistency of measurement (the consistency of measurement). (Vavrik et al., 2002).

Based on the results of the analysis using the Scale Reliability Test, the Cronbach Alpha value of each variable was obtained, as shown in the following table.

Table 9. Reliability Test Results

\begin{tabular}{|c|l|c|c|}
\hline No & \multicolumn{1}{|c|}{ Variable } & $\begin{array}{c}\text { Reliability Coefficient } \\
\text { (Alpha) }\end{array}$ & Description \\
\hline 1 & Leadership $\left(\mathrm{X}_{1}\right)$ & 0,761 & \multirow{2}{*}{ Reliable } \\
\cline { 1 - 2 } 2 & Professionality $\left(\mathrm{X}_{2}\right)$ & 0,763 & \\
\hline 3 & Work Facilities $\left(\mathrm{X}_{3}\right)$ & 0,764 & \\
\hline 5 & Ship and Goods Service $(\mathrm{Y})$ & 0,757 & \\
\hline
\end{tabular}

Source: Output SPSS 21

Based on the reliability test results above, the Cronbach Alpha value for the entire test scale is above 0.70, so it can be stated that the data collection instrument is acceptable and has met the validity requirements of an instrument.

\section{Normality test}

The normality test in the regression model is used to test whether the residual value resulting from the regression is normally distributed or not. The normality test in this study was carried out using the One-Sample Kolmogorov-Smirnov test.

Based on the results of the analysis using the One-Sample Kolmogorov Smirnov Test analysis tool, it can be seen that the Kolmogorov Smirnov value of each variable is as follows:

a. The Kolmogorov Smirnov score of the leadership variable is 4,177 .

b. The Kolmogorov Smirnov score for the professionalism variable was 5,138.

c. The Kolmogorov Smirnov score for the work facility variable was 5,187. 
d. The Kolmogorov Smirnov score of the ship and goods service variable was 5,216.

Based on the results of the normality test above, it can be seen that the overall Kolmogorov Smirnov value is $>0.05$, which means that all research variable data can be stated as normally distributed (attachment 8 Results of Normality Test).

\section{Linearity Test}

The linearity test aims to determine whether the regression model is linear or not. The analytical tool used is to use the $\mathrm{F}$ test or multiple regression. A regression model can be said to be linear if it meets the requirements of $F_{\text {count }}>F_{\text {table }}$.

Based on the results of the analysis on the linearity test, it was obtained that the Fcount value was 160,853 and the Ftable df value (309) was 3.871. Means that Fcount $(160,853)>$ Ftable $(3,871)$. Thus it can be stated that it meets the requirements and the model is linear (attachment 10d Table Anova).

\section{Multicollinearity Test}

The multicollinearity test aims to determine whether there is a correlation between the independent variables (independent). If the independent variables are correlated, these variables are not orthogonal so that they cannot be tested using a regression model. To determine whether there is multicollinearity between the independent variables, it can be seen from the tolerant value and the inflation factor (VIF) variant. According to Ghozali (2016: 104), the decision making criteria for using tolerant and VIF values is if the tolerant value is> 0.10 or the VIF value $<10$, then there is no multicollinearity among the independent variables. Conversely, if the tolerant value $\leq 0.10$ or the VIF value $\geq 10$, then there is multicollinearity among the independent variables.

Table 10. Multicollinearity Test Results

\begin{tabular}{|l|c|c|c|}
\hline \multicolumn{1}{|c|}{ Variable } & Tolerance & VIF & Description \\
\hline Leadership (X1) & 1,000 & 1,000 & Multicollinearity \\
\cline { 1 - 2 } Apparatus Professionalism (X2) & 1,000 & 1,000 & does not occur \\
\cline { 1 - 2 } Work Facilities (X3) & 1,000 & 1,000 & \\
\hline
\end{tabular}

Source: Output SPSS 21

Based on the table of multicollinearity test results above, it can be seen that the overall tolerance value obtained is 1,000 , which means $>0.1$ and the overall VIF value obtained is 1,000 which means <10. Thus, it can be stated that in this multicollinearity test, multicollinearity does not occur (Appendices 10a, 10b, 10c, 10d Coefficientsa Tables).

\section{Heteroscedasticity Test}

The heteroscedasticity test aims to test whether, in a regression model, there is an inequality of variance or residuals from one observation to another. According to Gujarati (2012), to test the presence or absence of heteroscedasticity, the Spearman rho test is used, which is by correlating the independent variable to the absolute value of the residual (error). If the correlation coefficient between the independent variable and the absolute value of the residual is significant, then the conclusion is that there is heteroscedasticity (the variant of the residual is not homogeneous).

Based on the results of the heteroscedasticity test, the respective correlation coefficients between the independent variables and the residuals were obtained, namely (1) The correlation coefficient between the Leadership variable and Unstandardized Residuals resulted in a significance value of 1,000. (2) The correlation coefficient between the 
Apparatus Professionalism variable and the Unstandardized Residual results in a value of 0.968. (3) The correlation coefficient between Work Facilities and Unstandardized Residual variables results in a value of 0.761 .

Based on the results of the heteroscedasticity test, it can be seen that the significance value of the correlation is $>0.05$, so it can be stated that the regression model does not find any heteroscedasticity problems.

\section{Hypothesis test}

Hypothesis testing is a procedure carried out with the aim of deciding whether to accept or reject a hypothesis. Hypothesis testing is the most important part of inference statistics (inductive statistics) because based on this test, decision making or problem-solving as a basis for further research can be resolved. The results of hypothesis testing in this study can be explained and described as follows:

\section{First Hypothesis Test}

H0: $b 1=0$ : there is no significant leadership influence on the quality ship and goods services from the perspective of authority at the Tanjung Priok Main Port Authority Office.

Ha: $b 1 \neq 0$ : there is a large leadership influence on the quality ship and goods services from the perspective of authority at the Tanjung Priok Main Port Authority Office.

\section{T-Test}

Based on the results of the analysis, the t-count value is 59,985 and the t-table value df (311) is 1.979 . It means that tcount (59.985)> ttable (1.967), then the leadership variable partially has a positive and significant effect on the quality ship and goods services. Thus it can be stated that the statement "there is a leadership influence on the quality ship and goods services in the perspective of the authority at the Tanjung Priok Main Port Authority Office" can be accepted and the hypothesis is proven.

\section{Determination Test}

Based on the results of the analysis, the coefficient of determination (R2) was 0.820 . This means that $82 \%$ of the diversity of ship services and quality goods is due to the diversity of leadership, while the rest (18\%) is due to other variables not included in this research model.

\section{Simple Linear Regression Equations}

Based on the results of the analysis, a simple linear regression equation is obtained as follows:

$-\hat{\mathrm{Y}}=\mathrm{a}+\mathrm{b} 1 \mathrm{X} 1$

$-\hat{\mathrm{Y}}=1.133+0.686 \mathrm{X} 1$

$-\hat{\mathrm{Y}}=1,819$.

This simple linear regression equation means that if the leadership is more effective in carrying out its leadership, the quality of the service will be, where at every 1 increase in the value of the leadership variable it can increase the value of ship service and quality goods by 1.819 assuming the variable professionalism of the apparatus and working facilities is constant. 


\section{Second Hypothesis Test}

$\mathrm{H} 0: \mathrm{b} 2=0$ : there is no significant influence of the professionalism of the officials on the quality ship and goods services from the perspective of the authority at the Tanjung Priok Main Port Authority Office.

Ha: $b 2 \neq 0$ : there is a big influence on the professionalism of the apparatus towards the service of quality ships and goods from the perspective of authority at the Tanjung Priok Main Port Authority Office.

\section{T-Test}

Based on the results of the analysis, the t-count value is 51.039 and the t-table value of $\mathrm{df}$ (311) is 1.979. It means that $t_{\text {count }}(51.039)>t_{\text {table }}(1.967)$, then the personnel professionalism variable partially has a positive and significant effect on the quality ship and goods services. Thus it can be stated that the statement "there is an influence of the professionalism of the officials on the service of quality ships and goods in the perspective of the authority at the Tanjung Priok Main Port Authority Office" can be accepted and the hypothesis is proven.

\section{Determination test}

Based on the results of the analysis, the coefficient of determination (R2) was 0.793 . This means that $79.3 \%$ of the diversity of ship services and quality goods is due to the diversity of professionalism of the apparatus, while the rest $(20.7 \%)$ is caused by other variables not included in this research model.

\section{Simple Linear Regression Equations}

Based on the results of the analysis in testing this hypothesis, a simple linear regression equation is obtained as follows:

$-\hat{\mathrm{Y}}=\mathrm{a}+\mathrm{b} 2 \mathrm{X} 2$

$-\hat{\mathrm{Y}}=1.191+0.675 \mathrm{X} 1$

- $\hat{Y}=1,866$.

This simple linear regression equation means that if the professionalism of the apparatus is higher, the quality of the service will be, where at every 1 increase in the value of the apparatus professionalism variable, it can increase the value of ship service and quality goods by 1.866 , assuming the variable leadership and work facilities are constant.

\section{Third Hypothesis Test}

H0: b3 = 0: there is no significant influence of work facilities on quality ship and goods services from the perspective of authority at the Tanjung Priok Main Port Authority Office.

Ha: $b 3 \neq 0$ : there is a large influence of work facilities on quality ship and goods services from the perspective of authority at the Tanjung Priok Main Port Authority Office.

\section{T-Test}

Based on the results of the analysis, the t-count value is 53,359 and the t-table value df (311) is 1.979 . It means that $t_{\text {count }}(53,359)>t_{\text {table }}(1,967)$, then the work facilities variable partially has a significant and positive influence on ship service and quality goods. Thus it can be stated that the statement "there is a large influence of work facilities on quality ship and goods services in the perspective of the authority at the Tanjung Priok Main Port Authority Office" can be accepted and the hypothesis is proven. 


\section{Determination test}

Based on the results of the analysis, the coefficient of determination (R2) was 0.802. This means that $80.2 \%$ of the diversity of ship services and quality goods is due to the diversity of work facilities, while the rest $(19.8 \%)$ is caused by other variables not included in this research model.

\section{Simple Linear Regression Equations}

Based on the results of the analysis in testing this hypothesis, a simple linear regression equation is obtained as follows:

$-\hat{Y}=a+b 2 X 2$

$-\hat{\mathrm{Y}}=1.166+0.688 \mathrm{X} 1$

$-\hat{\mathrm{Y}}=1,854$.

This simple linear regression equation means that if the work facilities are more adequate in its implementation, the better the quality of the service, where at every 1 increase in the value of the work facilities variable, it can increase the value of ship service and quality goods by 1.854 with the assumption of leadership and professionalism variables.

Fourth Hypothesis Test

$\mathrm{H} 0: \mathrm{b} 1=\mathrm{b} 2=\mathrm{b} 3=\mathrm{b} 4=0$ : there is no significant influence of leadership, the professionalism of the apparatus, and work facilities together on the quality ship and goods services from the perspective of authority at the Tanjung Priok Main Port Authority Office.

Ha: one or the fourth bi $\neq 0, \mathrm{i}=1,2,3,4$ : there is a large influence of leadership, professionalism of the apparatus and work facilities, and jointly on the quality ship and goods services from the perspective of authority at the Main Port Authority Office Tanjung Priok.

\section{F-Test}

Based on the results of the analysis, it was obtained that the $F_{\text {count }}$ value was 160,853 and the $F_{\text {table }}$ value for df (309) was 3.871. It means that $F_{\text {count }}(160,853)>F_{\text {table }}(3,871)$, it can be stated that the four variables have a positive and significant effect on the quality ship and goods services. Thus it can be stated that the statement "there is an influence of leadership, professionalism of officials and work facilities together on the quality ship and goods services in the perspective of authority at the Tanjung Priok Main Port Authority Office" can be accepted and the hypothesis is proven.

\section{Determination Test}

Based on the results of the analysis, the coefficient of determination (Adjusted R Square) is 0.839 . This means that $83.9 \%$ of the diversity of ship services and quality goods is due to the diversity of leadership, professionalism of officials, and work facilities together, while the rest $(16.1 \%)$ is caused by other variables not included in this research model.

\section{Multiple Linear Regression Equation}

1) Based on the results of the analysis in testing this hypothesis, the multiple linear regression equation is obtained as follows:

2) $-\hat{Y}=a+b 1 X 1+b 2 X 2+b 3 X 3$

3) $-\hat{\mathrm{Y}}=1.070+0.448 \mathrm{X} 1+0.240 \mathrm{X} 2+0.316 \mathrm{X} 3$ 
4) The definition of the multiple linear regression equation above can be interpreted as follows:

a. If the leadership is more effective in carrying out its leadership, the quality of ship and goods services will be in the perspective of authority at the Tanjung Priok Main Port Authority Office, where at every 1 increase in the value of the leadership variable can increase the value of the quality ship and goods services by 1.518 with variable assumptions professionalism of the apparatus and constant work facilities.

b. If the professionalism of the apparatus is higher in its implementation, the better the quality of ship and goods services in the perspective of authority at the Tanjung Priok Main Port Authority Office, where at every 1 increase in the value of the apparatus professionalism variable value can increase the value of the quality ship and goods services by 1.310 with the assumption leadership variables, and constant work facilities.

c. If the work facilities are more adequate in its implementation, the better quality of ship and goods services in the perspective of the authority at the Tanjung Priok Main Port Authority Office, where at each increase of 1 variable value of work facilities can increase the value of ship services and quality goods by 1.386 with the assumption variable of leadership and professionalism of the apparatus is constant.

Based on the results of the analysis, it is proven that leadership partially has a positive and significant influence on the quality ship and goods services from the perspective of authority at the Tanjung Priok Main Port Authority Office. The realization of the quality ship and goods services in an effort to provide satisfaction to the service user community requires leadership who has techniques for maturing and preparing followers, human relations techniques, exemplary techniques, persuasion techniques and giving orders and techniques for using suitable communication systems, so as to support ship services and goods and goods.

This is in line with the limitations put forward by Pamudji (2001: 114), that leadership is a way which is a fixed pattern for influencing people to move in the direction the leader wants. This understanding can be interpreted that quality ship and goods services can satisfy the service user community based on leadership that is able to influence people to move in the direction desired by the leader. As it is known that a smart leader is not a guarantee for leading an effective and efficient organization, because a leader in addition to having the knowledge and skills to lead is also required to be able to influence people to move in the direction the leader wants.

Based on the findings in the research results, it can be seen that the indicators that play an important role in the service of ships and quality goods are able to motivate subordinates, behave positively, and have good communication skills. Indicators are able to motivate subordinates to have an important role in leadership to realize quality ship and goods services. Motivating subordinates according to Birke et al (2004) is a form of transformational leadership, namely a leadership pattern that can motivate employees by bringing high aspirations and values to achieve the organization's vision and mission which is the basis for forming trust in leadership.

In relation to service, leadership is a very important factor in influencing the performance of an organization or institution because leadership is the main activity to achieve organizational goals because with this leadership it can increase the motivation factor of employees so that they can achieve more and overall can improve organizational or institutional performance. in the form of service quality (Chang \& Lee, 2007; Insani, 2020). 
Leadership is indispensable if an organization wants to progress and be successful, moreover good employees always want to know how they can contribute their participation to achieve goals and at least the passion of employees requires leadership as a basis for external motivation to keep their goals in harmony. with organizational goals. So an organization knows that the performance of a successful organization or institution has one common trait that causes the organization to be distinguished from other unsuccessful organizations, these traits and characteristics are effective leadership.

Based on the results of the analysis, it is proven that the professionalism of the apparatus partially has a positive and significant effect on the quality ship and goods services. The realization of the quality ship and goods services in an effort to provide satisfaction to the service user community requires the professionalism of officials who have a fairly good level of knowledge, skill level, and attitude/behavior so that they can support ship and cargo and goods services.

Professionalism is a person's ability and skills in doing work according to their respective fields and levels. This understanding can be interpreted that the service of ships and goods and goods can satisfy the service user community based on a person's ability and skills in doing the work owned by the apparatus when providing services (Lande et al., 2017).

Based on the results of the analysis it is proven that the work facilities partially have a positive and significant effect on the quality ship and goods services. The realization of quality ship services and goods in an effort to provide satisfaction to service users requires adequate work facilities.

Based on the results of the analysis, it is proven that leadership, the professionalism of the apparatus, and working facilities together have a positive and significant effect on the quality ship and goods services. The Tanjung Priok Main Port Authority is one of the government agencies/institutions as a public service provider who is required to provide quality services. Public ship and cargo services indicate a service activity carried out by the service provider, in this case, the government, to market or distribute products by prioritizing the satisfaction and expectations of the community as customers (demander) which in this case are in accordance with service standards and principles of public service. If the services provided by the Tanjung Priok Main Port Authority can be received or felt (perceived service) is as expected by service users, then ship and goods services can be perceived as good or satisfactory.

As stated by Sinambela (2010: 5), public service is the fulfillment of people's wants and needs by government officials with a series of activities carried out by the public bureaucracy to meet community needs. The implication of this research is that most of the respondents gave a response by giving a statement that leadership has an influence on the quality ship and goods services. Effective leadership is leadership that is able to exploit the various potentials that surround it and is not just a center of position or strength but is an active interaction between effective components. The findings of the research show that realizing quality ship and goods services can be done through leadership, by concentrating on indicators of being able to motivate subordinates, behave positively, and have good communication skills.

From a leadership perspective, leadership is one of the key factors in organizational life, including in the public sector, including determining the effectiveness of public service. The role of leadership is very important in achieving the goals of an organization. In other words, the success and failure of an organization, including the delivery of satisfactory service, is largely determined by the quality of leadership. From a public service perspective, leaders must be able to bring public organizations to provide excellent service. Because in essence, 
the formation of public organizations is to provide services to the community. One of the roles of a leader in realizing quality ship and goods services is being able to motivate subordinates. The ability to motivate subordinates can be achieved when the leader is effective in a way that is a fixed pattern of influencing people to move in the direction the leader wants to complete a job and achieve a satisfactory level of results.

\section{Conclusion}

Leadership has a significant and positive effect of $82 \%$ on the quality ship and goods services from the perspective of authority at the Tanjung Priok Main Port Authority Office. Official professionalism has a significant and positive effect of $79.3 \%$ on the quality ship and goods services from the perspective of authority at the Tanjung Priok Main Port Authority Office. Work facilities have a significant and positive effect of $80.2 \%$ on the quality ship and goods services from the perspective of the authority at the Tanjung Priok Main Port Authority Office. The combination of leadership, apparatus professionalism, and work facilities together have a significant and positive effect of $83.9 \%$ on the quality ship and goods services in the perspective of authority at the Tanjung Priok Main Port Authority Office, therefore quality ship and goods services depend to services that are open/transparent, accountable and efficient, supported by leadership, the professionalism of the apparatus, work facilities so that quality ship and goods services in the perspective of authority at the Tanjung Priok Main Port Authority Office become even better.

\section{References}

Bate, P., Mendel, P., \& Robert, G. (2007). Organizing for quality: the improvement journeys of leading hospitals in Europe and the United States. CRC Press.

Birke, J., Lewis, K., Penton, A., Pittman, D., Tucker, A., \& Durand, C. (2004). The effectiveness of a modified wedge shoe in reducing pressure at the area of previous great toe ulceration in individuals with diabetes mellitus. Wounds-A Compendium $O f$ Clinical Research And Practice, 16(4), 109-114.

Chang, S. C., \& Lee, M. S. (2007). A study on relationship among leadership, organizational culture, the operation of learning organization and employees' job satisfaction. The learning organization.

Doherty, T. L., \& Horne, T. (2002). Managing public services--implementing changes: $a$ thoughtful approach to the practice of management. Psychology Press.

Gronn, P. (2003). The new work of educational leaders: Changing leadership practice in an era of school reform. Sage.

Gujarati, D. (2012). Econometrics by example. Macmillan.

Insani, N. (2020). Apparatus Professionalism and Public Service Ethics. Journal La Sociale, 1(1), 25-28.

Lander, M. W., Heugens, P. P., \& van Oosterhout, J. (2017). Drift or alignment? A configurational analysis of law firms' ability to combine profitability with professionalism. Journal of Professions and Organization, 4(2), 123-148.

Neuman, W. L., \& Kreuger, L. (2003). Social work research methods: Qualitative and quantitative approaches. Allyn and Bacon.

Vavrik, W. R., Pine, W. J., \& Carpenter, S. H. (2002). Aggregate blending for asphalt mix design: Bailey method. Transportation Research Record, 1789(1), 146-153. 